\title{
Research on the effect of the effective microorganisms, silver solution and colloidal nanosilver addition on the engine oil acid number (TAN)
}

ARTICLE INFO

Received: 26 June 2021

Revised: 26 July 2021

Accepted: 2 August 2021

Available online: 3 August 2021
In the article, acid number as a parameter characterizing engine oil were characterized. The next part of the article discusses the phenomenon of aging and degradation of engine oil. The factors that influence on this phenomenon have also been analyzed. In the further part of the article, the methodology of testing the used oil samples with the addition of effective microorganisms and silver solution was described. In the main part of the article the measuring test stand and acid number value for fresh and used oil compared to oils with the addition of microorganisms and a solution of silver and colloidal silver was shown. Next the analysis of the influence of these additives on the acid number value was made. The article was completed conclusions.

Key words: engine oil, acid number value, oil degradation, effective microorganisms, silver solution

This is an open access article under the CC BY license (http://creativecommons.org/licenses/BY/4.0/)

\section{Introduction}

In petroleum products a major problem is microbial contamination, which includes both fuel for automobiles, aviation, and marine, motor and transformer oils and lubricants and oil emulsions. As the industry and automotive industry expanded, including aviation and ships, the problem of microbial contamination has been found to be still current and becoming more widespread. Research has shown that living organisms of microorganisms can lead to work disruption and even damage to car engines, aircraft or ships [3, 12, 15].

The increase in microbial contamination of fuels and oils can be caused by a number of factors, including: changes in fuel sources and their quality, increased use of fuel additives that can provide compounds for microbial growth, and changes in fuel management and storage [6, $11,14]$.

Discussing the influence of microorganisms on the process of lubricating oil degradation was discussed in more detail in the article $[9,10]$.

Dynamic development of the automotive industry, as well as aviation and shipbuilding industry and the associated progressive growth for hydrocarbon fuels resulted in increased interest in microorganism development phenomena in fuels and oils as well as in fuel and lubricating oil installations $[2,4]$.

Currently, there are many methods of controlling or limiting microorganisms in petroleum products, such as physical methods, thermal decontamination and chemical methods, while the present study analyses the impact of the addition of the effective microorganisms, silver solution and colloidal nanosilver addition on the fresh and used engine oil acid number.

\section{Acid number as a parameter characterizing engine oil}

The acid number expresses the number of milligrams of potassium hydroxide needed to neutralize the free acids present in one gram of sample [18]. Another definition of acid number is a measure of the number of carboxyl groups of a chemical compound, e.g. a fatty acid. According to the EN 14104 standard, the analysis of the acid content of the operating oil is performed by diluting the sample with a mixture of solvents in the reaction flask. While mixing, the potassium hydroxide is titrated to effect a chemical reaction with the acid components in the sample.

When the endpoint of a chemical reaction is reached, the amount of titrant consumed is given in milligrams of potassium hydroxide per gram of sample $(\mathrm{mgKOH} / \mathrm{g})$.

The initial acid number (AN) value of the new oil is influenced by the amount of acid present in the additives. An increase in acis number is usually accompanied by an increase in oxidation, nitration and viscosity [20].

The total acid number value indicates to the crude oil refinery the potential of corrosion problems.

The oxidation process in lubricating oils takes place under the influence of excessive temperature and the presence of air. This process develops particularly intensively in the presence of small metal particles, which in this case are catalysts for the oxidation process [7]. The products of oxidation are usually acidic compounds, and their concentration is determined by the acid number.

An increase in the acid number has an adverse effect on the properties of lubricating and diesel oils. A significant concentration of acid number leads to the formation of the so-called "sludge" that clogs the channels responsible for the flow of oil. This prevents proper operation of the internal combustion engine [19].

\section{Aging and degradation of engine oil}

Engine oil ages and degrades over time. At some point in his work, he becomes unusable. It is influenced by the impurities accumulated in the oil, the exhaustion of the potential of additives and the oxidation process, which increases the acid number of the oil. So it is natural for the oil to darken at the same time. It shows that the oil is doing its job properly, trapping contaminants in its suspension until the next change. 
Abrasive by-products include dust and dirt that enter the engine, and proper maintenance of the engine and its accessories can minimize contaminants entering the lubrication system and extend engine life. Besides, normal wear of engine parts produces very small metal particles which are then collected by the oil and remain in its circulation. Despite the presence of oil filters to help keep particles as low as possible, they cannot be completely removed. Oil degradation is also influenced by combustion by-products, such as water vapor that condenses on the cylinder walls and then enters the oil in the crankcase, where it leads to deposits and corrosion. The combustion process produces acid gases which, like water vapor, condense at low temperatures on the cylinder walls and then enter the oil, also causing corrosion.

Incomplete combustion contributes to the formation of soot, carbon and other sediment-forming materials.

When the engine is just started or malfunctioning, unburned fuel builds up on the cylinder walls, leaking through the rings and entering the crankcase, where it reduces the viscosity of the oil.

Diluting the oil with fuel reduces the strength of the oil film and increases its consumption [14, 16].

\section{The research methodology}

In the conducted tests, the acid number of engine oil was measured. For this purpose the Titrator TitroMatic $2 \mathrm{~S}$ has been used (Fig. 1).

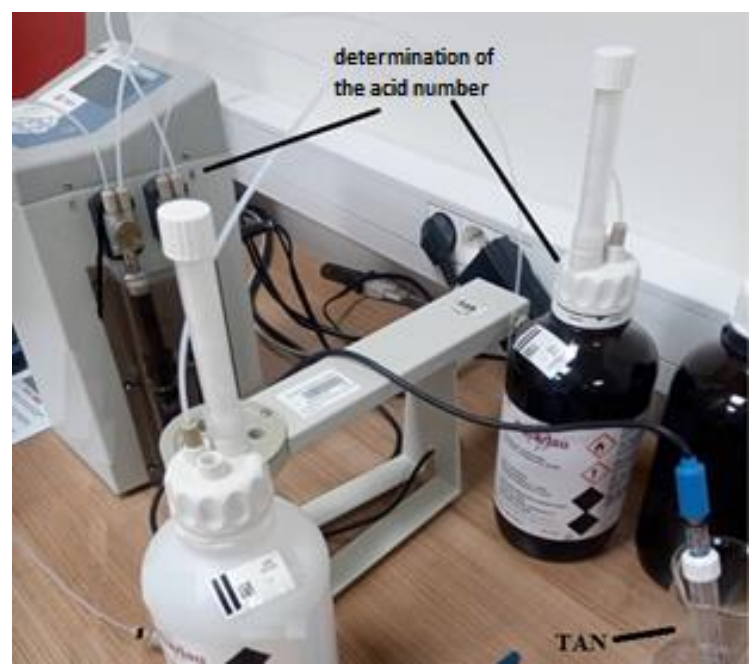

Fig. 1. Titrator TitroMatic $2 \mathrm{~S}$ device prepared to determine the acid number

Automatic titration apparatus - the TitroMatic $2 \mathrm{~S}$ titrator has two replaceable burettes. Both automatic piston digital burettes can work independently or together.

Additionally, the titrator used for the tests is equipped with a peristaltic pump for automatic dosing of reagents, mediating in the analysis process and automatic determination of the sample volume before titration.

The titrators automatically dose the titrant into the system until it reaches the set titration end point/set end value (Fig. 2): $\mathrm{pH}$ (e.g. $8.10 \mathrm{pH}$ for acidity determination, $4.65 \mathrm{pH}$ for Kjeldahl nitrogen determination) or $\mathrm{mV}$ (150 $\mathrm{mV}$ for chloride and $\mathrm{SO}_{2}$ ). Titrators automatically feed the reagent dynamically or in a fixed (linear) way to the end point (EP). They are characterized by a short analysis time. These devices have both dynamic and fixed (linear) modes, ensuring fast, precise and repeatable end point analysis [17].

Precise dosing near the end point $\mathrm{pH} / \mathrm{mV}$ of the set endpoint is shown in Fig. 2.

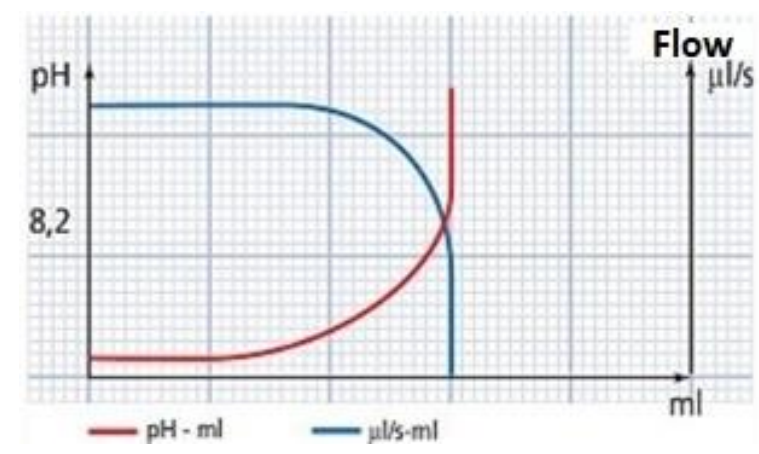

Fig. 2. Dosing near the endpoint $\mathrm{pH} / \mathrm{mV}$ of the set endpoint [17]

The tests were carried out using samples of the $5 \mathrm{~W} 30$ fresh and used motor oil.

Samples have the addition of effective microorganisms in liquid form in the amount of $2.5 \mathrm{ml}$ and $5 \mathrm{ml}$ and ceramic tubes in the amount of 3 pieces and 6 pieces. In addition, silver solution and colloidal nanosilver in the amount of $2.5 \mathrm{ml}$ and $5 \mathrm{ml}$ to fresh and used oil were added. Fresh oil and used oil without any additives were also tested to compare the acid number obtained.

One of the additives which improve the properties of oil are effective microorganisms $[1,8]$. They are specially selected the smallest organisms on Earth. It is a composition of 81 different strains of aerobic and anaerobic microorganisms, incl. lactic acid bacteria, yeast, photosynthetic bacteria and actinomycetes. This technology was developed by Teruo Higa, Professor of Horticulture at the Agricultural Academy of Ryukyus University in Okinawa, Japan. In trade, effective microorganisms exist in liquid form and as ceramic tubes. Effective microorganisms in the form of ceramic tubes are clay fermented with effective microorganisms and then fired under special anaerobic conditions. Effective microorganisms preserved in a ceramic form are characterized by the fact that they are resistant to high temperatures and maintain their beneficial properties for a long time. Effective microorganisms have a $\mathrm{pH}$ of 3.5 .

The second addition was non-ionic and ionic silver [5, 13]. Non-ionic silver, i.e. colloidal silver (research studies used silver with a concentration of $25 \mathrm{ppm}$ and $\mathrm{pH}$ 6-8). Colloidal silver is $80 \%$ of silver particles, while the remaining $20 \%$ are silver ions. It has a yellow color because the silver particles that are dispersed in the water block the light passing through them. Ionic silver is silver solution (research studies used silver with a concentration of

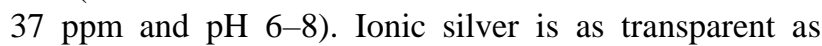
water. Ionic silver contains $90 \%$ silver ions and only about $10 \%$ silver particles. As $90 \%$ of the particles are silver ions, a more appropriate name is "silver solution". 
The samples were stored for eight weeks in a shade at $20^{\circ} \mathrm{C}$. The microorganisms were introduced after the process of oil degradation.

Before starting the tests, start the Titrator, connect the titrant (Potassium hydroxide) and the measuring electrode. The device is then calibrated with calibration fluids of known PH. After these steps, you can start the titration. First, a blank test is made in Mixture T.A.N. Then, you have to pour $20 \mathrm{ml}$ of oil (with a syringe) into a measuring cup, previously weighed and weigh the empty syringe. After a few minutes of titration, the acid value can be read off. Each sample was tested in triplicate and the final result is the mean of these measurements.

\section{Results and analysis of tests}

The test results of oil acid number are presented in the form of graphs in Fig. 3-6.

These graphs show different acid number values when added to fresh and used oil the effective microorganisms in liquid form $(2.5 \mathrm{ml}$ and $5 \mathrm{ml}$ per $100 \mathrm{ml}$ of oil $)$ and in the form of ceramic tubes ( 3 pieces and 6 pieces with a diameter of $9 \mathrm{~mm}$ and a height of $11 \mathrm{~mm}$ for $100 \mathrm{ml}$ of oil). In addition, silver solution and colloidal nanosilver were added to fresh and used oil in the same proportions as for th effective microorganisms $(2.5 \mathrm{ml}$ and $5 \mathrm{ml}$ per $100 \mathrm{ml}$ of oil).

Analysing the above results, it can be noticed for used oil (Fig. 3) that the acid number is $4.027 \mathrm{mgKOH} / \mathrm{g}$, while the addition of the effective microorganisms to the oil in the amount of $2.5 \mathrm{ml}$ and $5 \mathrm{ml}$, the acid number is 4.373 $\mathrm{mgKOH} / \mathrm{g}$ and $5.411 \mathrm{mgKOH} / \mathrm{g}$, respectively. This means that such an additive causes an even greater acidification of the oil and deterioration of its properties. Adding more effective microorganisms causes greater oil degradation. This means that the addition of effective microorganisms in a liquid form does not improve the properties of used oil.

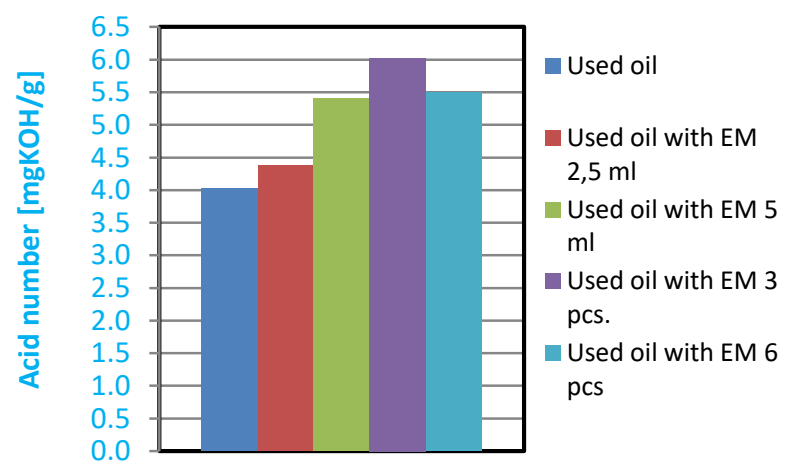

Fig. 3. Acid number of used oil and used oil with EM in liquid form and ceramic tubes

The effective microorganisms in the form of ceramic tubes in the amount of 3 and 6 also increase the acid number to the values of $6.027 \mathrm{mgKOH} / \mathrm{g}$ and 5.499 $\mathrm{mgKOH} / \mathrm{g}$, respectively, which also deteriorates the properties of the oil.

Adding any amount of effective microorganisms to the used oil degrades the properties of the oil, increasing the already high acid number. The analysis of the graph also shows that effective microorganisms in the form of ceramic tubes releases more microorganisms than in the liquid form, resulting in greater degradation of the oil.

In the case of adding $2.5 \mathrm{ml}$ of colloidal nanosilver to the used oil (Fig. 4), an increase in the acid number to $5.939 \mathrm{mgKOH} / \mathrm{g}$ can be observed, i.e. more by 1.912 $\mathrm{mgKOH} / \mathrm{g}$ compared to the value of this number for the used oil - no additive. On the other hand, the addition of 5 $\mathrm{ml}$ of non-ionic silver caused a slight decrease in the acid number in relation to the value for used oil by 0.277 $\mathrm{mgKOH} / \mathrm{g}$, therefore it is worth checking what effect would be achieved by adding more of this additive to the used oil.

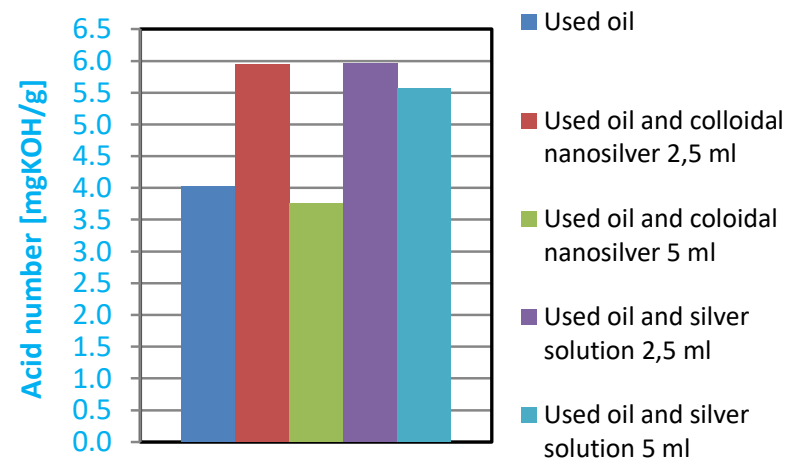

Fig. 4. Acid number of used oil and used oil with colloidal nanosilver and silver solution

The situation is different when adding $2.5 \mathrm{ml}$ and $5 \mathrm{ml}$ of silver solution. In both cases, the acid number increases to $1.929 \mathrm{mgKOH} / \mathrm{g}$ and $1.536 \mathrm{mgKOH} / \mathrm{g}$, respectively, in relation to the acid number value for the used oil. This means that this type of silver causes an even greater deterioration in the properties of the oil, although the greater amount of silver solution resulted in a lower increase in acid number, therefore the effect of adding more silver solution must be checked.

Summarizing, it can be concluded that the addition of silver does not improve the properties of used oil.

The acid number of the fresh oil is $2,560 \mathrm{mgKOH} / \mathrm{g}$. By adding $2.5 \mathrm{ml}$ of effective microorganisms, the acid number increases to $3.021 \mathrm{mgKOH} / \mathrm{g}$, while the addition of EM in the amount of $5 \mathrm{ml}$ causes a slight decrease in the acid number to $2.947 \mathrm{mgKOH} / \mathrm{g}$, i.e. more EM has a positive effect on the properties of the oil. In the case of adding EM in the form of ceramic tubes, the situation is similar, i.e. a smaller number of tubes increases the acid number to $3.113 \mathrm{mgKOH} / \mathrm{g}$, but 6 pieces of ceramic tubes reduces the acid number to $2.366 \mathrm{mgKOH} / \mathrm{g}$. This means that it would be worth checking the effect of adding EM in a larger amount and in the form of ceramic tubes to check the effect on the acid value of the fresh oil and the subsequent change in the value of this number after a certain period of operation in comparison with oil operated without this additive. 


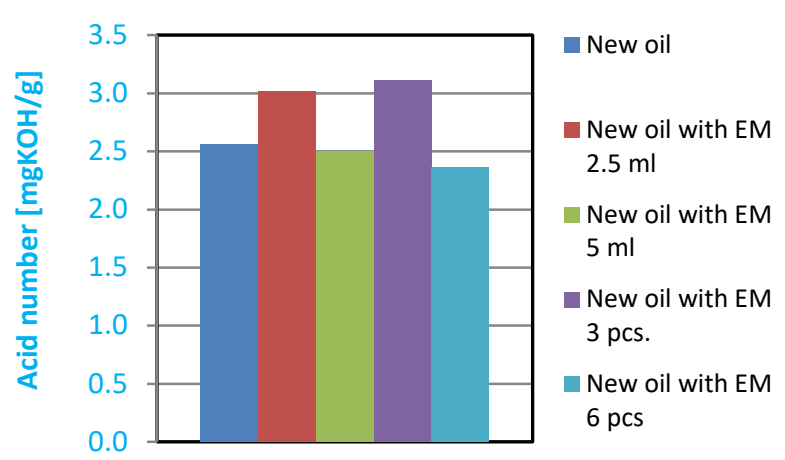

Fig. 5. Acid number of new oil and new oil with EM in liquid form and ceramic tubes

As in the case of used oil, the effect of adding silver solution and colloidal nanosilver to new oil was also investigated. The addition of $2.5 \mathrm{ml}$ of colloidal nanosilver to the oil increases the acid number to the level of 2.668 $\mathrm{mgKOH} / \mathrm{g}$, and in the amount of $5 \mathrm{ml}$ to the level of 2.659 $\mathrm{mgKOH} / \mathrm{g}$.

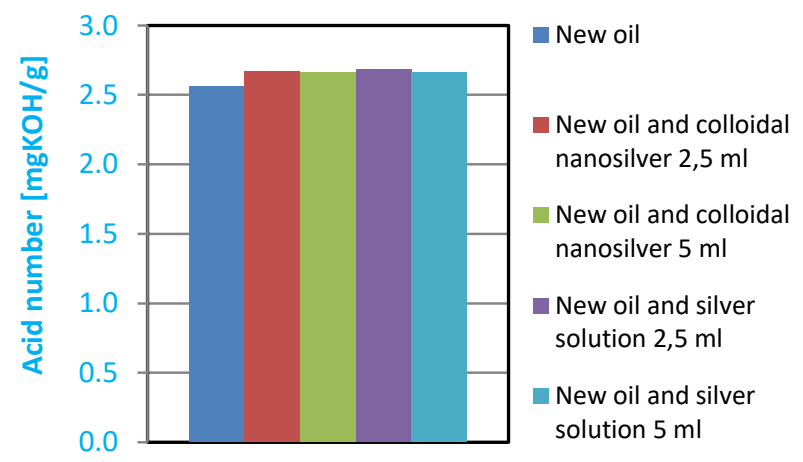

Fig. 6. Acid number of new oil and new oil with colloidal nanosilver and silver solution

Similar values can be observed after adding silver solution to the oil, i.e. for $2.5 \mathrm{ml}$ and $5 \mathrm{ml}$, the acid number is $2.682 \mathrm{mgKOH} / \mathrm{g}$ and $2.660 \mathrm{mgKOH} / \mathrm{g}$, respectively. Both types of silver there is a slight increase in the acid number in comparison to the acid number for new oil. Any amount and type of silver deteriorates the properties of the oil. Therefore, further testing with the addition of silver to new oil is not worthwhile.

\section{Conclusion}

The aim of the research was checking the effect of the addition of the effective microorganisms, silver solution and colloidal nanosilver on the acid number of used and fresh oil.

The addition of any effective microorganisms to the used oil deteriorates the properties of the oil, increasing the already high acid value.

The analysis of the graphs also show that the effective microorganisms in the form of ceramic tubes releases more microorganisms than in the liquid form, and then more oil degradation occurs.

Adding a smaller amount of colloidal nanosilver to the used oil causes an increase in the acid number, while in this larger amount it caused a slight decrease in the acid number in relation to the value for the used oil.

Therefore, it is worth checking the effect of adding more of this additive to the used oil.

When silver solution is added, the acid number increases compared to the acid number for used oil without additives. This means that this type of silver causes an even greater deterioration in the properties of the oil, although the greater amount of silver solution resulted in a lower increase in acid number, therefore, the effect of adding more silver solution must be examined.

Adding effective microorganisms to fresh oil in liquid form and the ceramic tube in a smaller quantity, the acid number increases, whereas in a larger amount results in a slight decrease in acid number. This means that more effective microorganisms have a positive effect on the properties of the oil.

It would be worth checking the effect of adding effective microorganisms in a larger amount and in the form of ceramic tubes to check the effect on the acid value of the fresh oil then change the value of this number after a certain period of use in comparison with oil operated without this addition.

The addition of colloidal nanosilver and silver solution to the oil causes a slight increase in the acid number compared to the acid number for new oil. Any amount and type of silver deteriorates the properties of the oil. Therefore, further testing with the addition of silver to new oil is not worthwhile.

\section{Nomenclature}

AN acid number

ASTM American Society for Testing Materials

EM effective microorganisms
EO end point
TAN total acid number

\section{Bibliography}

[1] BORUSZKO, D., BUTAREWICZ, A. Impact of effective microorganisms bacteria on low-input sewage sludge treatment. Environment Protection Engineering. 2015, 41(4), 8396. https://doi.org/10.5277/epe150407

[2] GAYlarde, C.C., BENTO, F., KELlEY, J. Microbial contamination of stored hydrocarbon fuels and its control. Revista de Microbiologia. 1999, 30(1), 1-10. https://doi.org/10.1590/S0001-37141999000100001 
[3] SAADAT HILL, E.C. Biodegradation of petroleum products. Petroleum microbiology. Atlas R.M (red.). Macmillan Publ. London. 1984, 579-619.

[4] JANDA, K. Mikrobiologiczne skażenie paliw. Postępy mikrobiologii. 2005, 44(2), 157-169.

[5] KIM, J.S. et al. Antimicrobial effects of silver nanoparticles. Nanomedicine: Nanotechnology, Biology, and Medicine. 2007, 3, 95-101. https://doi.org/10.1016/j.nano.2006.12.001

[6] KLOFUTAR, B., GOLOB, J. Microorganisms in diesel and in biodiesel fuels. Acta Chimica Slovenica. 2007, 54, 744758.

[7] KOHTOH, M., KANEKO S., OKABE S. et al. Aging effect on electrical characteristics of insulating oil in field transformer. IEEE Transactions on Dielectrics and Electrical Insulation. 2009, 16(6), 1698-1706.

https://doi.org/10.1109/TDEI.2009.5361592

[8] KOLASA-WIĘCEK, A. Czy efektywne mikroorganizmy zrewolucjonizują świat? Postępy Techniki Przetwórstwa Spożywczego. 2010, 1, 66-69.

[9] KRAKOWSKI, R. Problemy zanieczyszczeń występujących w produktach naftowych i ich usuwanie za pomocą środków przyjaznych środowisku naturalnemu. Autobusy: technika, eksploatacja, systemy transportowe. 2017, 18(6), 275-280.

[10] KRAKOWSKI, R. Zastosowanie efektywnych mikroorganizmów do zwalczania lub ograniczania drobnoustrojów w produktach naftowych. Autobusy: technika, eksploatacja, systemy transportowe. 2016, 17(12), 292-296.

[11] LASOCKI, J., KARWOWSKA, E. Wpływ mikroorganizmów bytujących w środowisku oleju napędowego i biodiesla na układ paliwowy pojazdów napędzanych silnikami o zapłonie samoczynnym. Archiwum Motoryzacji. 2010, 3, 167-183.
[12] MALINOWSKA, M. Analiza zanieczyszczeń oleju silnikowego stosowanego w silniku Cegielski-Sulzer 3AL25/30. Zeszyty Naukowe Akademii Morskiej w Gdyni. 2014, 83, 194-202.

[13] MIRZAJANI, F., GHASSEMPOUR, A., ALIAHMADI, A. et al. Antibacterial effect of silver nanoparticles on Staphylococcus aureus. Research in Microbiology. 2011, 162, 542549. https://doi.org/10.1016/j.resmic.2011.04.009

[14] NIEWCZAS, A., WRONA, J., WRONA, R. Zanieczyszczenia oleju smarującego oraz ich wpływ na trwałość silnika spalinowego. Autobusy : technika, eksploatacja, systemy transportowe. 2010, 11(6).

[15] PTAK, S., JAKÓBIEC, J. Ropa naftowa jako główny surowiec energetyczno-przemysłowy. Nafta-Gaz. 2016, 72(6), 451-460. https://doi.org/10.18668/NG.2016.06.09

[16] Czarne paliwo.

https://czarnepaliwo.wordpress.com/2015/03/23/starzeniesie-i-degradacja-oleju-silnikowego/ (accessed on 28.07.2021)

[17] Labindex.

http://www.labindex.pl/titratory/titratory_potencjometryczne (accessed on 28.07.2021)

[18] Machinery Lubrication.

https://www.machinerylubrication.com/Read/1052/acidnumber-test (accessed on 28.07.2021)

[19] Pomiary Automatyka Robotyka. http://www.par.pl/Forummlodych/Studenckie-Kolo-Naukowe-Nano/pomiar-ianaliza-zawartoci-liczby-kwasowej-wnanomodyfikowanych-olejach-elektroizolacyjnych (accessed on 28.07.2021)

[20] Zmien Olej. https://zmienolej.pl/pl/blog/kompendiumwiedzy/analiza-laboratoryjna-oleju-badanie-silnikow-podkatem-liczby-zasadowej-tbn-oraz-liczby-kwasowej-tan (accessed on 28.07.2021)

Rafał Krakowski, DEng. - Faculty of Marine Engineering, Gdynia Maritime University

e-mail: r.krakowski@wm.umg.edu.pl 